\title{
Influence of phosphocompost application on phosphorus availability and uptake by maize grown in red soil of Ishigaki Island, Japan
}

\author{
Farid Abdel Aziz Hellal ${ }^{1 *}$, Fuji Nagumo², Raffat Metwally Zewainy ${ }^{1}$ \\ ${ }^{1}$ Department of Plant Nutrition, National Research Centre, Cairo, Egypt; ${ }^{*}$ Corresponding Author: hellalaf@yahoo.com \\ ${ }^{2}$ Japan International Research Center for Agricultural Sciences, Soil and Water Management Group, Okinawa, Japan
}

Received 12 December 2012; revised 15 January 2013; accepted 22 January 2013

\begin{abstract}
Phospho compost application is important with respect to soil fertility and plant nutrition. Therefore, the objective was to evaluate the influence of phospho compost application on $\mathrm{P}$ availability and uptake by maize in red soil. The phosphorus applied in the form of phospho compost, as compare to rock phosphate and super phosphate at a rate of 50 and $100 \mathrm{mg} \mathrm{P}_{2} \mathrm{O}_{5} \mathrm{Kg}^{-1}$ soil. The application was done as spot and mix application. Results indicate that, spot application of $100 \mathrm{mg} \mathrm{P} \mathrm{O}_{5} \mathrm{~kg}^{-1}$ soil as phospho compost (b) registered significantly higher $P$ uptake $(2.1$ and $5.31 \mathrm{mg} \cdot$ pot $\left.^{-1}\right)$ and available soil $P$ (19.1 and 21.0 $\left.\mathrm{mg} \cdot \mathrm{kg}^{-1}\right)$ as compare to Rock Phosphate alone $\left(0.60\right.$ and $\left.0.97 \mathrm{mg} \cdot \operatorname{pot}^{-1}\right)$ and $\left(5.6\right.$ and $\left.6.0 \mathrm{mg} \cdot \mathrm{kg}^{-1}\right)$ at 30 and 60 day after sowing, respectively. The probable chelating effect from phospho composting increased the phosphorus use efficiency and resulted into higher relative agronomic efficiency in phospho compost (b) spot application ( $40 \%$ ) over mix application (15\%). The dry matter yield had positive and significant correlation with available $P$ in soil and $P$ uptake by maize plants at 30 and 60 day after sowing. Results concluded that phospho compost enriched with FYM was most effective in increasing phosphorus availability in red soil and increasing dry matter yield of maize plants.
\end{abstract}

Keywords: Phosphocompost; Rock Phosphate; Available P; Maize; Red Soil

\section{INTRODUCTION}

Overexploitation and abusive use of chemical fertilizers led to soils poorer in humus content. Composting can not only transform waste by reducing its harmful effect but also corrects when added to soil, the deficit in organic matter. Therefore, if agriculture is to meet the demand for food, the development of soil atmosphere that exhibits higher crop yield, is imperative. The inadequate supply of essential plant nutrients in soil is a growth-limiting factor towards production. Among all the elements required by a plant, phosphorus is one of the most important nutrients for crop production, and emphasis is being given on the efficient use of $\mathrm{P}$ fertilizer for sustainable crop production [1].

Phosphorus has a vital role in energy storage, root development and early maturity of crops. The availability of soil phosphorus is enhanced by addition of organic manures, presumably due to chelation of cations by organic acids and other decay products. The $\mathrm{P}$ requirement of crops is very high during initial stages of plant growth. An adequate $P$ supply from soil and fertilizer is, therefore, necessary. In general, the uptake of P by plants is almost complete towards the end of the period of maximum growth. The common and recommended practice of $P$ application is to broadcast and incorporate in the soil before sowing. Earlier studies showed little utility of applied $\mathrm{P}$ before sowing until first irrigation to wheat crop [2]. Phosphorus plays a series of functions in the plant metabolism and is one of the essential nutrients required for plant growth and development. It has functions of a structural nature in macromolecules such as nucleic acids and of energy transfer in metabolic pathways of biosynthesis and degradation. Unlike nitrate and sulphate, phosphate is not reduced in plants but remains in its highest oxidized form [3]. Phosphorus inputs are required for sustainable agricultural production in most acid soils of the tropics and subtropics. Rock phosphate rocks and organic materials have been suggested as alternative $\mathrm{P}$ sources in these soils. Phosphorus deficiency is a major constraint to crop production in tropical and subtropical acid soils and P fertilizers need to be applied to obtain optimum plant growth and crop yields. Direct application of rock phosphate (RP) has been mainly used in these soils, especially for perennial crops. 
However, PRs usually do not perform as well as watersoluble P fertilizers with annual crops in terms of yield response [4]. [5] found that uniform placement of SSP and PR significantly enhanced plant growth and P uptake by rye grass grown on two Typic Hapludults, but failed to show that water soluble $P$ increased plant utilization of a low reactive PR from China. Rock phosphate offers a good alternative or complement to superphosphate in volcanic soils of Chile and it is recommended to apply RP in combination with triple superphosphate because of the high P retention capacity of these soils [6].

The high cost of importing soluble $\mathrm{P}$ fertilizers is, therefore, forcing many developing countries to turn increasingly to using local rock phosphate (RP) resources to improve agricultural production [7]. Composting manure and/or biological waste with RP has been shown to enhance the dissolution of the RP [8] and is practiced widely as a low-input technology to improve the fertilizer value of manure [9]. Compositing of rock phosphates with agricultural wastes is known to increase solubility of rock phosphates. [10] studied the effect of rock phosphate amended with poultry manure on soil available phosphate and yield of maize and cowpea grown sequentially was evaluated for four cropping seasons. The results obtained showed the effectiveness of rock phosphate as a $\mathrm{P}$ sources for crop production was remarkably enhanced by solubilizing effect of poultry manure. [11] indicated a reasonable possibility could be existed for the application of the rock phosphates directly as fertilizers instead of the industrial ones under certain conditions. Moreover, the application of phosphate rock natural fertilizers combined with amendments of organic manures may improve the phosphorous solubilization and availability. This application is more friendly environmental with respect to the environmental concerns and impacts. Composting process of rice straw enriched with rock phosphate decrease the concentration of total carbon, NH4-N, C:N ratio, and increase the total nitrogen (TN), soluble phosphorous, and organic acid (Formic, Citric, Lactic and Acetic acids). Detection of these organic acids may indicate their role in $\mathrm{P}$ solubility. The phospho-composted produced with FYM enrichment can be considered a rich $\mathrm{P}$ fertilizer for increasing $\mathrm{P}$ solubility and crop production, [12]. The objectives of this study was to determine the role of phosphocompost on Phosphorus availability in soil and uptake by plant and enhancing the agronomic effectiveness as compare to the alternative $P$ sources and their effects on the performance of maize yield grown in acidic red soil.

\section{MATERIALS AND METHODS}

\subsection{Location}

To achieve the objectives of the study, pot experiment were conducted in the greenhouse of the Japan International Research Center for Agricultural Sciences (JIRCAS) at the Tropical Agricultural Research Front (TARF), at Ishigaki Island $\left(24^{\circ} \mathrm{N}, 129^{\circ} \mathrm{E}\right)$ a core among the most southern Ryukyu Island. The climate is subtropical with winter and summer rainy seasons.

\subsection{Soil Preparation}

The soil used for the pot experiment was excavator at a mountain in the Ishigaki Island. This soil is probably classified as a red Ultisol. Physical and chemical analyses of soils used in pot experiment in Table 1 were determined according to the methods reported by [13]. By using the subsoil, we assume that the available P might be very low so effect of $\mathrm{P}$ application can be observed in our study. The soil was air dried in the greenhouse for one week before breaking. Then after, it was sieved to pass $2 \mathrm{~mm}$. pots were collected, washed with water and air dried. The determination of water holding capacity of the soil was done to help for fixing the quantity of water to be applied to the pots daily during the maize growth.

\subsection{Pot Experiments}

Three seeds of maize were planted in each pot containing $4.42 \mathrm{~kg}$ of red soil. The experimental design was randomized complete block design with four replications. The treatment characterization and its arrangement in pot experiment as follow in Table 2.

Single superphosphate contains $18 \%$ of total $\mathrm{P}$ and Burkina Faso rock phosphate (BRP) characterized by: $\mathrm{Ca}$ (\%) 32.0; $\mathrm{CO}_{2}$ (\%) 1.0; K (\%) 0.119; $\mathrm{Na}(\%)$ 0.605; $\mathrm{Mg}$ (\%) 1.06; Fe (\%) 0.375; Al (\%) 0.488; S (\%) 0.025; Cl (\%) 0.043 ; F (\%) 3.2; total P (\%) 10.69; soluble P (\%) 0.032 and $\mathrm{PO}_{3} / \mathrm{CO}_{3}=23$. Phosphocompost (a): contains rice straw $+10 \%$ Burkina Faso rock phosphate $+2.5 \%$ Asperigillus niger, composted for about four month and characterized by: total P (\%) 1.62; water soluble P (354.4 $\mathrm{mg} \cdot \mathrm{kg}^{-1}$ ) and $\mathrm{C} / \mathrm{N}$ ratio (15.6).

Phosphocompost (b) contains rice straw $+10 \%$ Burkina Faso rock phosphate $+2.5 \%$ Asperigillus niger + $10 \%$ Farmyard manure, composted for about four month and characterized by: total P (\%) 1.92; water soluble P (1041.3 $\mathrm{mg} \cdot \mathrm{kg}^{-1}$ ) and $\mathrm{C} / \mathrm{N}$ ratio (13.4).

All the pots received uniformly $\mathrm{Ca}\left(9.60 \mathrm{~g}\right.$ of $\mathrm{Ca}(\mathrm{OH})_{2}$ pot $^{-1}$ ) equivalent to $60 \mathrm{~kg} \mathrm{Ca}(\mathrm{OH})_{2} \mathrm{ha}^{-1}$, N (1.89 g ammonium sulphate $\operatorname{pot}^{-1}$ ) equivalent to $100 \mathrm{~kg} \mathrm{Nha}^{-1}$ and $\mathrm{K}\left(0.633 \mathrm{~g} \mathrm{KCl} \mathrm{pot}^{-1}\right)$ equivalent to $100 \mathrm{~kg} \mathrm{~K}_{2} \mathrm{O} \mathrm{ha}{ }^{-1}$ that were broadcast and mix applied to the soil in the pots. The applications of calcium contribute to manipulate the soil acidity from 4.75 to 5.50 . The soil moisture level of all pots was kept at $60 \%$ of the field capacity during growth of the plants. One week after full growth, the seedlings were thinned to two plants per pot. Samples 
Table 1. Characteristics of initial soil.

\begin{tabular}{ccccccccc}
\hline $\begin{array}{c}\text { Textural } \\
\text { Class }\end{array}$ & $\begin{array}{c}\text { Soil } \mathrm{pH} \\
(1: 2.5)\end{array}$ & $\begin{array}{c}\text { Soil EC } \\
\left(\mathrm{dS} \cdot \mathrm{m}^{-1}\right)\end{array}$ & $\begin{array}{c}\text { CEC } \\
\left(\mathrm{c} \mathrm{mol}(\mathrm{P}+) \mathrm{kg}^{-1}\right)\end{array}$ & $\begin{array}{c}\text { Total P } \\
\left(\mathrm{mg} \cdot \mathrm{kg}^{-1}\right)\end{array}$ & $\begin{array}{c}\text { Water Soluble P } \\
\left(\mathrm{mg} \cdot \mathrm{kg}^{-1}\right)\end{array}$ & $\begin{array}{c}\text { Available P } \\
\left(\mathrm{mg} \cdot \mathrm{kg}^{-1}\right)\end{array}$ & $\begin{array}{c}\text { PAC } \\
\left(\mathrm{mg} \cdot \mathrm{kg}^{-1}\right)\end{array}$ \\
\hline Clay loam & 5.95 & 0.372 & 14.8 & 117.0 & 2.3 & 3.2 & 7.6 \\
\hline
\end{tabular}

PAC: P absorption coefficient.

Table 2. Treatment details applied in pot experiment.

\begin{tabular}{cl}
\hline \multicolumn{1}{c}{ Treatment details } \\
\hline T0 & Control without $\mathrm{P}_{2} \mathrm{O}_{5}$ application \\
$\mathrm{T} 1$ & $50 \mathrm{~m} \mathrm{P}_{2} \mathrm{O}_{5} \mathrm{~kg}^{-1}$ soil as super phosphate spot application \\
$\mathrm{T} 2$ & $50 \mathrm{mg} \mathrm{P}_{2} \mathrm{O}_{5} \mathrm{~kg}^{-1}$ soil as rock phosphate spot application \\
$\mathrm{T} 3$ & $50 \mathrm{~m} \mathrm{P}_{2} \mathrm{O}_{5} \mathrm{~kg}^{-1}$ soil as Phoshocompost (a) spot application \\
$\mathrm{T} 4$ & $50 \mathrm{~m} \mathrm{P}_{2} \mathrm{O}_{5} \mathrm{~kg}^{-1}$ soil as Phoshocompost (b) spot application \\
$\mathrm{T} 5$ & $100 \mathrm{~m} \mathrm{P}_{2} \mathrm{O}_{5} \mathrm{~kg}^{-1}$ soil as super phosphate spot application \\
$\mathrm{T} 6$ & $100 \mathrm{~m} \mathrm{P}_{2} \mathrm{O}_{5} \mathrm{~kg}^{-1}$ soil as rock phosphate spot application \\
$\mathrm{T} 7$ & $100 \mathrm{~m} \mathrm{P}_{2} \mathrm{O}_{5} \mathrm{~kg}^{-1}$ soil as Phoshocompost (a) spot application \\
$\mathrm{T} 8$ & $100 \mathrm{mg} \mathrm{P}_{2} \mathrm{O}_{5} \mathrm{~kg}^{-1}$ soil as Phoshocompost (b) spot application \\
$\mathrm{T} 9$ & $100 \mathrm{mg} \mathrm{P}_{2} \mathrm{O}_{5} \mathrm{~kg}^{-1}$ soil as super phosphate mix application \\
$\mathrm{T} 10$ & $100 \mathrm{mg} \mathrm{P}_{2} \mathrm{O}_{5} \mathrm{~kg}^{-1}$ soil as rock phosphate mix application \\
$\mathrm{T} 11$ & $100 \mathrm{mg} \mathrm{P}_{2} \mathrm{O}_{5} \mathrm{~kg}^{-1}$ soil as Phoshocompost (a) mix application \\
$\mathrm{T} 12$ & $100 \mathrm{mg} \mathrm{P}_{2} \mathrm{O}_{5} \mathrm{~kg}^{-1}$ soil as Phoshocompost (b) mix application \\
\hline
\end{tabular}

from the rhizosphere soils and the plants were collected at 30 and 60 days from planting for subsequent determinations. Lived leaf number, plant height, and leaf area per plant estimated at 60 days.

Available $\mathrm{P}$ of the soil samples was determined at 30 and 60 day from sowing using Bray 1:0.03 $\mathrm{M} \mathrm{NH}_{4} \mathrm{~F}+$ $0.025 \mathrm{M} \mathrm{HCl}$. For the determination of phosphorous and nitrogen in plant root and shoot, the whole dried plant material from each pot was pulverized. A representative sample of exactly $0.5 \mathrm{~g}$ was digested using sulphuric acid and hydrogen peroxide. The digest was quantitatively transferred into a $50 \mathrm{ml}$ volumetric flask and estimation was done by [14]. Relative agronomic efficiency (RAE) was calculated using next equation. $\mathrm{RAE}=($ Dry matter from treatment-Dry matter from control) divided by (Dry matter from SSP-Dry matter from control) into 100. The P use efficiency (PUE) and P balance of the trial was assessed. $\mathrm{PUE}=(\mathrm{P}$ uptake from treatment $-\mathrm{P}$ uptake from control) divided by Applied P into 100.

\subsection{Statistical Analysis}

The data obtained were subjected to analysis by the SPSS statistical program (SPSS for Windows 2007). The values presented are the average of four replicates and the treatment means differences were evaluated by the Duncan Range Test at $\mathrm{P}=0.05$ according to [15]. Pearson correlation determinations were also performed be- tween dry matter produced and available $\mathrm{P}$ in soil and plant $\mathrm{P}$ uptake at 30 and 60 days after sowing.

\section{RESULTS AND DISCUSSION}

\subsection{Growth Parameters}

Data in Table 3 showed that, dry matter yield, lived leaf number, plant height and leaf area per plant of maize were significantly higher in spot application as compared with mix application. Mean values of spot application treatments received single super phosphate (SP) were in general slightly higher than the ones treated with Phosphocompost (a) or (b) and lowest recorded in rock phosphate treatment. Among the spot application treatments, the treatment $\mathrm{T} 5$ of $100 \mathrm{mg} \mathrm{P}_{2} \mathrm{O}_{5} \mathrm{~kg}^{-1}$ soil as super phosphate produced the highest dry matter, lived leaf number, plant height and leaf area followed by T1 (50 mg $\mathrm{P}_{2} \mathrm{O}_{5} \mathrm{~kg}^{-1}$ soil as super phosphate), T8 (100 mg $\mathrm{P}_{2} \mathrm{O}_{5}$ $\mathrm{kg}^{-1}$ soil as Phoshocompost (b)), T7 (100 mg $\mathrm{P}_{2} \mathrm{O}_{5} \mathrm{~kg}^{-1}$ soil as Phoshocompost (a)), T3 (50 $\mathrm{mg} \mathrm{P}_{2} \mathrm{O}_{5} \mathrm{~kg}^{-1}$ soil as Phoshocompost (a)) and the lowest recorded in rock phosphate treatment. Progressive application of compost produce a better vegetative growth of maize in all plots where compost was applied than where PR was directly applied without composting it, [16].

In mix application treatments, T9 $\left(100 \mathrm{mg} \mathrm{P}_{2} \mathrm{O}_{5} \mathrm{~kg}^{-1}\right.$ soil as super phosphate) and T12 \{100 mg $\mathrm{P}_{2} \mathrm{O}_{5} \mathrm{~kg}^{-1}$ soil as Phoshocompost (b) $\}$ registered significantly higher over other treatments followed by T11 $\left\{100 \mathrm{mg} \mathrm{P}_{2} \mathrm{O}_{5}\right.$ $\mathrm{kg}^{-1}$ soil as Phoshocompost (a) $\}$ and the lowest was T10 (100 $\mathrm{mg} \mathrm{P}_{2} \mathrm{O}_{5} \mathrm{~kg}^{-1}$ soil as rock phosphate). In pot treated with rock phosphate (RP), no significant increases were observed at the rate or the methods of application used. [17] applied RP to mono-cropped maize and concluded that the RP fertilizer did not affect maize yield. According to these results, application of $50 \mathrm{mg} \mathrm{P}_{2} \mathrm{O}_{5} \mathrm{~kg}^{-1}$ soil as super phosphate or $100 \mathrm{mg} \mathrm{P}_{2} \mathrm{O}_{5} \mathrm{~kg}^{-1}$ soil as Phoshocompost (b) as spot or mix application proved signifycantly higher maize growth parameters as compare to other treatments and lowest was in rock phosphate treatment. The non-readily available $\mathrm{P}$ sources as rock phosphate showed lower growth parameters at the applied $\mathrm{P}$ rate, compared to composted rock phosphate. It is reported that observed differences in plant response could be explained by the very different dissolution behaviors of rock phosphates [18]. 
Table 3. Effect of $\mathrm{P}$ application on maize growth parameters and relative agronomic efficiency.

\begin{tabular}{|c|c|c|c|c|c|c|}
\hline \multirow{2}{*}{ Treatments } & \multirow{2}{*}{$\begin{array}{c}\text { Dry matter } \\
(\mathrm{g}) / \text { plant at } 60 \text { day }\end{array}$} & \multirow{2}{*}{$\begin{array}{l}\text { Lived Leaf } \\
\text { No. at } 60 \text { day }\end{array}$} & \multirow{2}{*}{$\begin{array}{l}\text { Plant height } \\
(\mathrm{cm}) \text { at } 60 \text { day }\end{array}$} & \multirow{2}{*}{$\begin{array}{c}\text { Leaf area } \\
\left(\mathrm{cm}^{2} / \text { plant }\right) \text { at } 60 \text { day }\end{array}$} & \multicolumn{2}{|c|}{$\begin{array}{l}\text { Relative agronomic } \\
\text { efficiency }\end{array}$} \\
\hline & & & & & 30 day & 60 day \\
\hline T0 & $0.81 \mathrm{~d}$ & $2.3 \mathrm{~d}$ & $44.5 \mathrm{~g}$ & $21.2 \mathrm{~g}$ & - & - \\
\hline $\mathrm{T} 1$ & $28.20 \mathrm{~b}$ & $8.7 b$ & $121.7 \mathrm{~b}$ & 1687.c0 & $100 \mathrm{a}$ & $100 \mathrm{a}$ \\
\hline $\mathrm{T} 2$ & $0.54 \mathrm{~d}$ & $2.3 \mathrm{~d}$ & $43.3 \mathrm{~g}$ & $43.7 \mathrm{~g}$ & $-18.38 \mathrm{a}$ & $-0.87 \mathrm{c}$ \\
\hline T3 & $8.94 b c$ & $7.0 \mathrm{~b}$ & $73.2 \mathrm{de}$ & $688.3 \mathrm{e}$ & $31.82 \mathrm{a}$ & $26.54 b c$ \\
\hline $\mathrm{T} 4$ & $16.80 \mathrm{bc}$ & $7.3 \mathrm{~b}$ & $84.3 \mathrm{de}$ & $1053.3 \mathrm{~d}$ & $99.85 \mathrm{a}$ & $43.46 \mathrm{~b}$ \\
\hline T5 & $39.09 \mathrm{a}$ & $10.0 \mathrm{a}$ & $132.7 \mathrm{a}$ & $2028.7 b$ & $100 \mathrm{a}$ & $100 \mathrm{a}$ \\
\hline T6 & $2.61 \mathrm{~cd}$ & $4.0 \mathrm{c}$ & $58.3 \mathrm{f}$ & $237.3 \mathrm{f}$ & $-3.32 \mathrm{~d}$ & $2.69 \mathrm{c}$ \\
\hline $\mathrm{T} 7$ & $12.15 b c$ & $7.7 \mathrm{~b}$ & 83.5 fde & $807.0 \mathrm{e}$ & $25.38 \mathrm{c}$ & $30.25 b$ \\
\hline $\mathrm{T} 8$ & $18.96 b c$ & $8.3 b$ & $91.0 \mathrm{~d}$ & $1104.7 \mathrm{~d}$ & $38.06 \mathrm{~b}$ & $39.48 b$ \\
\hline T9 & $44.91 \mathrm{a}$ & $8.3 \mathrm{~b}$ & $112.7 \mathrm{c}$ & $2480.7 \mathrm{a}$ & $100 \mathrm{a}$ & $100 \mathrm{a}$ \\
\hline $\mathrm{T} 10$ & $0.81 \mathrm{~d}$ & $2.3 \mathrm{~d}$ & $45.2 \mathrm{~g}$ & $48.3 \mathrm{~g}$ & $-44.04 c$ & $0.49 \mathrm{c}$ \\
\hline T11 & $7.32 \mathrm{bc}$ & $3.7 \mathrm{~cd}$ & $47.5 \mathrm{~g}$ & $136.0 \mathrm{f}$ & $-22.36 \mathrm{c}$ & $0.56 \mathrm{c}$ \\
\hline $\mathrm{T} 12$ & $12.96 b c$ & $7.3 b$ & $89.5 d$ & $1123.3 \mathrm{~d}$ & $30.18 b$ & $15.36 \mathrm{~b}$ \\
\hline
\end{tabular}

\subsection{Relative Agronomic Efficiency}

Relative agronomic efficiency (RAE) was calculated at the base of dry matter considering control is zero and 100 SP is $100 \%$ in Table 3. Significant differences were observed due to levels and methods of $\mathrm{P}$ application. The higher RAE was observed at 30 day after sowing as compare to 60 day after sowing indicate increasing the $\mathrm{P}$ availability with time especially with phosphocompost treatment as compare to rock phosphate. Application of $100 \mathrm{mg} \mathrm{P}_{2} \mathrm{O}_{5} \mathrm{~kg}^{-1}$ soil as Phoshocompost (b) spot application was significantly higher RAE over Phoshocompost (a) and rock phosphate treatments. For the application rate of $50 \mathrm{mg} \mathrm{P}_{2} \mathrm{O}_{5} \mathrm{~kg}^{-1}$ soil, only the RAE of the Phoshocompost (b) treatment was higher than Phoshocompost (a) and rock phosphate. [9] concluded that composting poultry manure with PR not only reduces environmental pollution associated with manure application, but also increases the agronomic effectiveness of manure. No differences were found between the Phoshocompost (b) treatment and the rock phosphate application as spot application at 30 and 60 day after sowing. This index was found to be a good parameter to compare differences in effectiveness between P sources. Science the a agronomic effectiveness of rock phosphate as fertilizer is favored by soils that have low $\mathrm{pH}$, low calcium and $\mathrm{p}$ status of the soil solution [19] as well as p demanding crops such as maize, groundnut, cotton and cacao.

\subsection{Phosphorus Uptake}

Significant differences were observed with spot application of T5 (100 mg $\mathrm{P}_{2} \mathrm{O}_{5} \mathrm{~kg}^{-1}$ soil as super phosphate) on $\mathrm{P}$ uptake at $30\left(5.50 \mathrm{mg} \cdot \mathrm{kg}^{-1}\right)$ and 60 days $(16.5$ $\mathrm{mg} \cdot \mathrm{kg}^{-1}$ ) as compare with other P treatment and control of no $\mathrm{P}$ applied (Table 4). Whereas, no significant differences observed between RP as spot or mix at any applied levels over control one. At 30 day after sowing, spot application of $100 \mathrm{mg} \mathrm{P}_{2} \mathrm{O}_{5} \mathrm{~kg}^{-1}$ soil as Phoshocompost (b) (T8) registered significantly higher total $\mathrm{P}$ uptake $\left(2.10 \mathrm{mg} \cdot \mathrm{kg}^{-1}\right)$ over T4 application of P (1.40 $\left.\mathrm{mg} \cdot \mathrm{kg}^{-1}\right)$ and $\mathrm{T} 12$ phosphocompost treatments $(0.75$ $\left.\mathrm{mg} \cdot \mathrm{kg}^{-1}\right)$. The application of Phospho-compost at T8 was significantly higher $\mathrm{P}$ uptake $\left(5.30 \mathrm{mg} \cdot \mathrm{kg}^{-1}\right)$ over $\mathrm{Rp}$ treatment and control without $\mathrm{P}$ and did not vary significantly over other compost treatments applied as spot or mix applications at the levels used. The increase in $\mathrm{P}$ uptake was most likely due to a better plant establishment due to an early root development induced by the water soluble $\mathrm{P}$, enabling the plant to use more effectively the other $P$ source. The average enhancement effect across $\mathrm{P}$ rates was higher for the phosphocompost than rock phosphate. The highest $\mathrm{P}$ uptake in Phosphocompost treatments could be attributed to the greater leaf biomass yield in phosphocompost treated soil as compared to rock phosphate or any other treatment. The $\mathrm{P}$ uptake by root followed similar trend at 60 day after sowing. Spot application of T8 registered significantly higher total $\mathrm{P}$ uptake $\left(2.10 \mathrm{mg} \cdot \mathrm{kg}^{-1}\right)$ over T4 application of $\mathrm{P}\left(1.40 \mathrm{mg} \cdot \mathrm{kg}^{-1}\right)$ and $\mathrm{T} 12$ compost treatments $(0.75$ $\left.\mathrm{mg} \cdot \mathrm{kg}^{-1}\right)$. The application of phospho-compost at $\mathrm{T} 8$ was significantly higher $\mathrm{P}$ uptake $\left(5.30 \mathrm{mg} \cdot \mathrm{kg}^{-1}\right)$ over RP treatment and control without $\mathrm{P}$ and did not vary significantly over other compost treatments applied as spot or mix applications at the levels used. [20] concluded that the combined application of compost and town refuse with rock phosphate is important to increase the growth 
Table 4. $\mathrm{P}$ input, outputs and $\mathrm{P}$ balance and phosphorus use efficiency during maize growth.

\begin{tabular}{|c|c|c|c|c|c|c|c|}
\hline \multirow{2}{*}{ Treatments } & $\mathrm{P}$ inputs & $\begin{array}{l}\text { P uptake } \\
\text { at } 30 \text { days }\end{array}$ & $\begin{array}{l}\text { P uptake } \\
\text { at } 60 \text { day }\end{array}$ & TP uptake & \multirow[t]{2}{*}{ P balance } & \multicolumn{2}{|c|}{ Phosphorus use efficiency } \\
\hline & \multicolumn{4}{|c|}{$\mathrm{mg} \cdot \operatorname{pot}^{-1}$} & & 30 day & 60 day \\
\hline T0 & 0 & $0.53 \mathrm{~d}$ & $0.32 \mathrm{c}$ & $0.84 \mathrm{c}$ & $-0.84 \mathrm{e}$ & - & - \\
\hline $\mathrm{T} 1$ & 87.2 & $2.70 \mathrm{~b}$ & $12.60 \mathrm{a}$ & $15.40 \mathrm{ab}$ & $71.80 \mathrm{~d}$ & $5.03 \mathrm{a}$ & $14.14 \mathrm{a}$ \\
\hline $\mathrm{T} 2$ & 87.2 & $0.39 \mathrm{~d}$ & $0.26 \mathrm{c}$ & $0.65 \mathrm{c}$ & $86.60 \mathrm{c}$ & $-0.32 b$ & $-0.06 \mathrm{c}$ \\
\hline $\mathrm{T} 3$ & 87.2 & $0.85 \mathrm{~cd}$ & $2.50 \mathrm{bc}$ & $3.40 \mathrm{c}$ & $83.80 \mathrm{c}$ & $0.74 \mathrm{~b}$ & $2.53 \mathrm{bc}$ \\
\hline $\mathrm{T} 4$ & 87.2 & $1.40 \mathrm{~cd}$ & $2.90 \mathrm{bc}$ & $4.30 \mathrm{c}$ & $82.90 \mathrm{c}$ & $2.03 b$ & $2.90 \mathrm{bc}$ \\
\hline T5 & 174.4 & $5.50 \mathrm{a}$ & $16.50 \mathrm{ab}$ & $22.00 \mathrm{a}$ & $152.40 \mathrm{~b}$ & $5.71 \mathrm{a}$ & $9.27 \mathrm{ab}$ \\
\hline $\mathrm{T} 6$ & 174.4 & $0.60 \mathrm{~d}$ & $0.97 \mathrm{c}$ & $1.60 \mathrm{c}$ & $172.80 \mathrm{a}$ & $0.08 b$ & $0.38 \mathrm{c}$ \\
\hline $\mathrm{T} 7$ & 174.4 & $1.30 \mathrm{~cd}$ & $3.00 \mathrm{c}$ & $4.30 \mathrm{c}$ & $170.10 \mathrm{a}$ & $0.87 \mathrm{~b}$ & $1.55 \mathrm{c}$ \\
\hline $\mathrm{T} 8$ & 174.4 & $2.10 \mathrm{bc}$ & $5.30 \mathrm{bc}$ & $7.50 \mathrm{bc}$ & $166.90 \mathrm{a}$ & $1.85 \mathrm{~b}$ & $2.87 \mathrm{bc}$ \\
\hline T9 & 174.4 & $1.50 \mathrm{bcd}$ & $26.00 \mathrm{a}$ & $27.50 \mathrm{a}$ & $146.90 \mathrm{~b}$ & $1.13 \mathrm{~b}$ & $14.73 a$ \\
\hline $\mathrm{T} 10$ & 174.4 & $0.40 \mathrm{~d}$ & $0.44 \mathrm{c}$ & $0.84 \mathrm{c}$ & $173.60 \mathrm{a}$ & $-0.14 b$ & $0.07 \mathrm{c}$ \\
\hline T11 & 174.4 & $0.46 \mathrm{~d}$ & $0.56 \mathrm{c}$ & $1.00 \mathrm{c}$ & $173.40 \mathrm{a}$ & $-0.07 b$ & $0.14 \mathrm{c}$ \\
\hline $\mathrm{T} 12$ & 174.4 & $0.75 \mathrm{~d}$ & $3.40 \mathrm{c}$ & $4.20 \mathrm{c}$ & $170.20 \mathrm{a}$ & $0.26 \mathrm{~b}$ & $1.77 \mathrm{c}$ \\
\hline
\end{tabular}

and yield parameter and $\mathrm{P}$ uptake by faba bean plants over application rock phosphate to soil without organic amendments.

\subsection{Phosphorus Use Efficiency}

Phosphorus use efficiency (PUE) was calculated depending on $P$ uptake at 30 and 60 day divided by the applied P (Table 3). PUE increased with time and with increasing the level and methods of $\mathrm{P}$ application. PUE was significantly higher in super phosphate spot application over all other treatment at 30 and 60 days. At 60 days, application of $\mathrm{T} 8\left(100 \mathrm{mg} \mathrm{P}_{2} \mathrm{O}_{5} \mathrm{~kg}^{-1}\right.$ soil as Phoshocompost (b) spot application) was significantly higher as compare to Super phosphate spot application (T5) and did not vary significantly with T7 and T6. In mix application treatment, significant differences were observed only in case of super phosphate treatment over all applied treatments. Phosphorus use efficiency was higher in Phoshocompost as compared to other fertilizers. As the total dose of $\mathrm{P}$ applied to each pot was the same, greater uptake of $\mathrm{P}$ from Phoshocompost resulted in the highest $\mathrm{P}$ use efficiency from this source. This $\mathrm{P}$ use efficiency of different fertilizers followed the order: super phosphate $>$ Phoshocompost (b) $>$ Phoshocompost (a) $>$ rock phosphate. Phosphorus from Burkina Faso rock phosphate was solubilized and transformed into available forms when it was incorporated during composting of rice straw. Maize utilized phosphorus efficiently from the phosphorus enriched compost containing $1.6 \%-1.9 \% \mathrm{P}$ when added in the acidic soil.

\section{5. $\mathrm{P}$ Balance}

The accumulated $\mathrm{P}$ balances are shown in Table 4. $\mathrm{P}$ balance was calculated for pot experiment taken into account $\mathrm{P}$ inputs at planting and $\mathrm{P}$ uptake at 30 and 60 day after sowing. Phosphorus remaining in the soil was significantly higher with the treatment rock phosphate over super phosphate and did not significantly differ with phosphocompost treatments. When any application of $\mathrm{P}$ was not done in the control treatment, the P balance was negative $\left(-0.84 \mathrm{mg} \cdot \mathrm{pot}^{-1}\right)$.

\subsection{Root and Shoot $P$}

Data in Figure 1 indicated that, the $\mathrm{P}$ uptake by root at 60 day was in the following order: T9 $>$ T5 $>$ T8 $>$ T1 . Whereas, in shoot, it was as follows: T9 $>\mathrm{T} 5>\mathrm{T} 8>\mathrm{T} 1$. Mix application was higher P uptake by root over spot application. Root: Shoot ratios of $\mathrm{P}$ uptake at 60 day after sowing were significantly higher in phosphocompost treatments T4 (3.14), T7 (2.85), T8 (2.40), T3 (2.29) and the lowest registered in rock phosphate treatments. This indicates that the distribution of $\mathrm{P}$ between root and shoot was better under the application of phosphocompost as compare to super phosphate and rock phosphate.

\subsection{Available Soil Phosphorus}

The highest available $\mathrm{P}$ was found with spot application of super phosphate and Phosphocompost (b) treatment at 30 and 60 day of sowing. On the control pots, without $P$ fertilization, the available $P$ contents decreased with time. Application of $\mathrm{P}$ fertilizers, however, increased the available $\mathrm{P}$ contents of the soils. For both inorganic (super phosphate) and organic (phosphocompost) $\mathrm{P}$ sources, the available $\mathrm{P}$ contents in soil were higher than those of the rock phosphate $\mathrm{P}$ source. However, the treatment receiving T5 $\left(100 \mathrm{mg} \mathrm{P}_{2} \mathrm{O}_{5} \mathrm{~kg}^{-1}\right.$ soil 


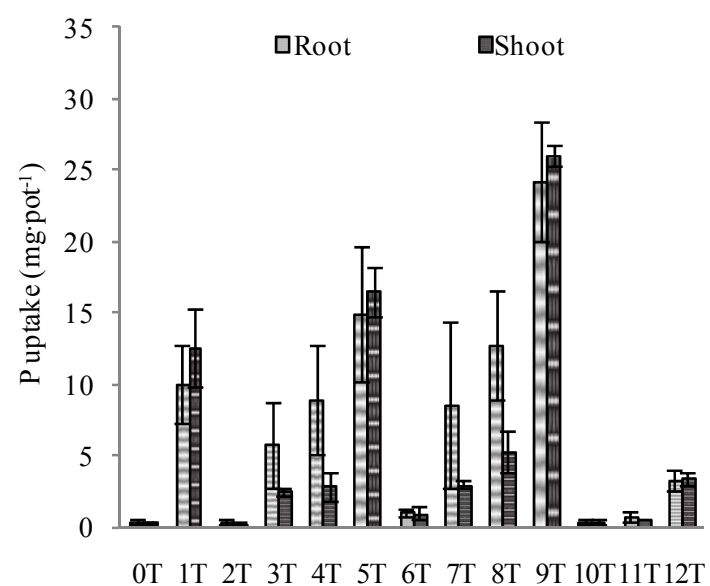

Figure 1. Uptake of $\mathrm{P}$ as affected by sources of $\mathrm{P}$ application at 60 days.

as super phosphate spot application) has shown the highest available P after extraction of P by Bray I methods over all other treatments at different applied levels (Figure 2). The ranking of $P$ released was as follow: at 30 days, T5 (100 mg $\mathrm{P}_{2} \mathrm{O}_{5} \mathrm{~kg}^{-1}$ soil as super phosphate spot

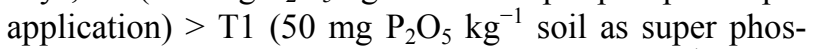
phate spot application $)>\mathrm{T} 8\left(100 \mathrm{mg} \mathrm{P}_{2} \mathrm{O}_{5} \mathrm{~kg}^{-1}\right.$ soil as Phoshocompost (b) spot application) > T7 (100 mg $\mathrm{P}_{2} \mathrm{O}_{5}$ $\mathrm{kg}^{-1}$ soil as Phoshocompost (a) spot application). Phosphorus from Burkina Faso rock phosphate (MRP) was solubilized and transformed into available forms when it was incorporated during composting of rice straw. Maize utilized phosphorus efficiently from the phosphorus enriched compost containing $1.6 \%-1.9 \% \mathrm{P}$ when added in the soil of pH 5.5 to 5.8. While at 60 DAS, T5 $(100 \mathrm{mg}$ $\mathrm{P}_{2} \mathrm{O}_{5} \mathrm{~kg}^{-1}$ soil as super phosphate spot application) $>\mathrm{T} 8$ (100 mg $\mathrm{P}_{2} \mathrm{O}_{5} \mathrm{~kg}^{-1}$ soil as Phoshocompost (b) spot application $)=\mathrm{T} 1\left(50 \mathrm{mg} \mathrm{P}_{2} \mathrm{O}_{5} \mathrm{~kg}^{-1}\right.$ soil as super phosphate spot application $)>\mathrm{T} 7\left(100 \mathrm{mg} \mathrm{P}_{2} \mathrm{O}_{5} \mathrm{~kg}^{-1}\right.$ soil as Phoshocompost (a) spot application) $>\mathrm{T} 4\left(50 \mathrm{mg} \mathrm{P}_{2} \mathrm{O}_{5} \mathrm{~kg}^{-1}\right.$ soil as Phoshocompost (b) spot application). [21] concluded that, co-composting is the maintenance of $\mathrm{P}$ in a potentially plant-available form through the uptake and storage of $\mathrm{P}$ in the microbial biomass, which is subsequently turned over making the $\mathrm{P}$ available.

When co-composting RP, the initial dissolution/decomposition phase is followed by uptake, transformation and storage of solubilied $\mathrm{P}$ within the microbial biomass, and finally a variable period of stabilisation and humification of organic P-containing compounds, the extent of which will depend on storage conditions and duration. From 30 to 60 days the $P$ availability was increased significantly with phosphocompost application. The application of organic P sources (phosphocompost) accelerate the $\mathrm{P}$ dissolution and increase the available soil $\mathrm{P}$ in red soil over rock phosphate application alone without composting thus increased uptake and content of $\mathrm{P}$ in maize.

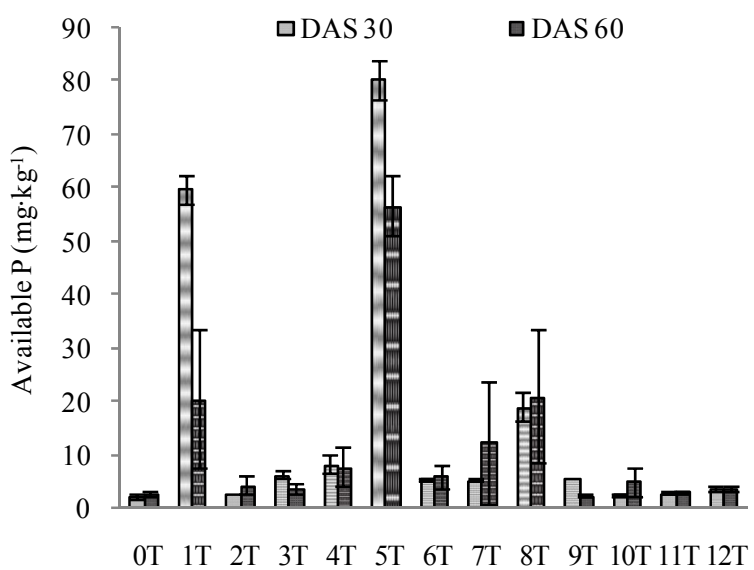

Figure 2. Available $\mathrm{P}$ in soil as affected by sources of $\mathrm{P}$ application.

The results of $\mathrm{P}$ enriched compost preparation (phosphocompost) and its effect on crop yield clearly demonstrated that Burkina Faso rock phosphate is solubilized during composting and the solubilizing action is due to humic substances which have chelating action.

\subsection{Relationship between Dry Matter of Maize and Available Soil $P$}

The highest effect of Super phosphate and Phoshocompost (b) treatments on dry matter production was due to the significant relationship between dry matter and available soil $P$ in Figures 3 and $\mathbf{4}$. The regression coefficient between dry weight and available soil $\mathrm{P}$ at 30 day was $\mathrm{R}^{2} 0.725^{* *}$ and with available soil $\mathrm{P}$ at 60 day was $\mathrm{R}^{2}$ $0.298^{* *}$. The decreasing regression values between 30 and 60 days may be due to increasing the root distribution and $\mathrm{P}$ uptake at 60 days over 30 days.

\subsection{Correlation Study}

The data on correlation coefficient between dry matter yield and nutrient uptake during maize growth are presented in Table 5. The results of the investigation indicated that at 30 day, dry matter yield was significantly and positively correlated with available soil phosphorus $\left(0.851^{* *}\right)$ and $\mathrm{P}$ uptake $\left(0.981^{* *}\right)$. Whereas, at 60 days, significant and positive correlation were observed between dry matter and available soil $\mathrm{P}\left(0.514^{* *}\right)$ and $\mathrm{P}$ uptake $\left(0.860^{* *}\right)$. However, negative correlation was observed between available soil $\mathrm{P}$ and soil $\mathrm{pH}$ at 60 day after sowing.

\section{CONCLUSION}

Phoshocompost had a significant and direct role compared to inorganic single super phosphate on dry matter yield and $\mathrm{P}$ uptake in maize plants. The $\mathrm{P}$ use efficiency in maize was higher due to phoshocompost application 
Table 5. Person correlation between dry matter yield and nutrient uptake during maize growth.

\begin{tabular}{ccccccc}
\hline \multirow{2}{*}{ Parameters } & \multicolumn{3}{c}{30 day after sowing } & \multicolumn{3}{c}{60 day after sowing } \\
\cline { 2 - 7 } & Dry matter yield & Available soil P & P uptake & Dry matter yield & Available soil P & P uptake \\
\hline Available soil P & $0.851^{* *}$ & & & $0.514^{* *}$ & & \\
P uptake & $0.981^{* *}$ & $0.896^{* *}$ & & $0.860^{* *}$ & $0.449^{* *}$ & $-0.326^{*}$ \\
Soil pH & $0.433^{* *}$ & $0.357^{* *}$ & $0.405^{* *}$ & -0.141 & -0.231 \\
\hline
\end{tabular}

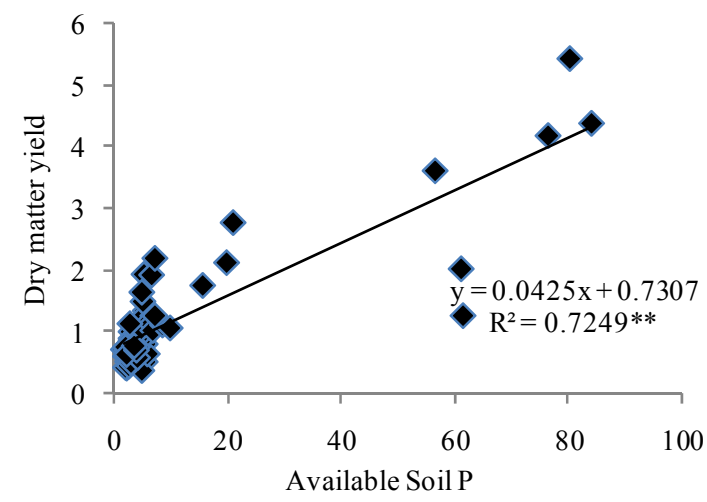

Figure 3. Relationship between dry matter and available soil $P$ at 30 day.

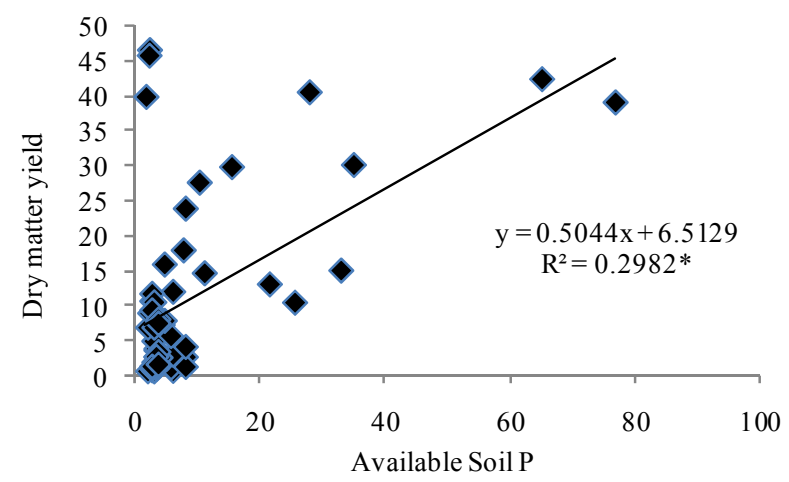

Figure 4. Relationship between dry matter and available soil $P$ at 60 day.

as compared to rock phosphate. Hence emphasis is to be given on the decomposition time and mineralization rate of phoshocompost fertilizers for improving crop production from the acidic red soil.

\section{ACKNOWLEDGEMENTS}

This study was supported by the Japan International Centre for Agricultural Sciences (JICAS), Ishigaki, Okinawa, Japan. The authors are grateful to all technical staff in soil and water management group especially for their sincere helps during the study time.

\section{REFERENCES}

[1] Ryan, I. (2002) Efficient use of phosphate fertilizers for sustainable crop production in WANA. Phosphate Newsletter, 2-5.
[2] Latif, A., Alam, S.M., Zafar I. and Hamid, A. (1992) Effect of rate, time and method of application of $P$ fertilizer on wheat crop. Proceedings of the 4th National Congress of Soil Science, Islamabad, 24-26 May 1992, 299-303.

[3] Marschner, H. (1993) Mineral nutrition of higher plants. Academic Press, Waltham.

[4] Chien, S.H. and Friesen, D.K. (1992) PR for direct application. Future Directions for Agricultural Phosphorus Research, National Fertilizer and Environmental Research Center, Muscle Shoals, 47-52.

[5] Xiong, L.M., Zhou, Z.G. and Lu, R.K. (1996) Enhanced plant growth by uniform placement of superphosphate with rock phosphate in acidic soils. Communications in Soil Science and Plant Analysis, 27, 2837-2850. doi: $10.1080 / 00103629609369745$

[6] Pino, I. and Casas, L. (1990) Phosphoric rock appraisal in volcanic ash soils of Chile. Transactions of the14th International Congress of Soil Science, 4, 122-125.

[7] Van Straaten, P. (2002) Rocks for crops: Agro minerals of sub-Saharan Africa. ICRAF, Nairobi, 338.

[8] Singh, C.P. and Amberger, A. (1991) Solubilization and availability of phosphorus during decomposition of phosphate rock enriched straw and urine. Biological Agriculture and Horticulture, 7, 261-269. doi:10.1080/01448765.1991.9754553

[9] Mahimairaja, S., Bolan, N.S. and Hedley, M.J. (1995) Dissolution of phosphate rock during the composting of poultry manure: An incubation experiment. Fertilizer Research, 40, 93-104. doi:10.1007/BF00750093

[10] Akande, M.O., Adediran J.A. and Oluwatoyinbo, F.I. (2005) Effects of rock phosphate amended with poultry manure on soil available $p$ and yield of maize and cowpea. African Journal of Biotechnology, 4, 444-448.

[11] Rania, M. (2011) Studies on solubilization and fertilization by phosphate ores and behavior of their associated elements in some Egyptian soils. Ph.D. Thesis, Faculty of Agriculture, Ain Shams University, Cairo.

[12] Hellal, F.A., Nagumo, F. and Zewainy, R.M. (2012) Influence of phospho-composting on enhancing phosphorus solubility from inactive rock phosphate. Australian Journal of Basic and Applied Sciences, 6, 268-276.

[13] Rebecca, B. (2004) Soil survey methods manual. Soil Survey Investigations Report No. 42, Natural Resources Conservation Services.

[14] Motsara, M.R. and Roy, R.N. (2008) Guide to laboratory establishment for plant nutrient analysis. Food and Agriculture Organization of the United Nations, Rome.

[15] Gomez, K.A. and Gomez, A.A. (1984) Statistical procedures for agriculture research. 2nd Edition, John Wiley 
and Sons Inc., New York.

[16] Nyirongo, J.C.V.B., Mughogho S.K. and Kumwenda J.D.T. (1999) Soil fertility studies with compost and igneous phosphate rock amendments in Malawi. African Crop Science Journal, 7, 415-422. doi:10.4314/acsj.v7i4.27735

[17] Tossah, B.K. (2000) Influence of soil properties and organic inputs on $\mathrm{P}$ cycling in herbaceous legume-based cropping systems in west African derived savanna. Ph.D. Thesis, University of Kansas, Leuven.

[18] Gilkes, R.J. and Bolland, M.D.A. (1990) The Australian experience with rock phosphate: Limitations and explanations. Phosphate Sources for Acid Soils in the Humid Tropics of Asia. Proceedings of the Workshop, Kuala Lumpur, 6-7 December 1990, 177-205.
[19] Amapu, I.Y., Chude, V.O., Iwuafor, E.N.P. and Babalola, O.A. (1999) Soil and fertilizer factors influencing the utilization of phosphate rock in the sub-humid Nigeria savanna. Proceedings of Book of Abstracts 25th Annual conference, Benin, 21-25 November 1999, 35.

[20] Hellal, F.A., Abd El-Hady, M. and Ragab, A.A.M. (2009) Influence of organic amendments on nutrient availability and uptake by faba bean plants fertilized by rock phosphate and feldspar. American-Eurasian Journal of Agriculture and Environmental Sciences, 6, 271-279.

[21] The Institute of Organic Training and Advice (2010) Composting with rock phosphate: Increasing plant-available $\mathrm{P}$. Institute of Organic Training \& Advice, Shropshire. www.organicadvice.org.uk 